\title{
Determination of Optimal Irrigation Scheduling for Onion (Allium Cepa L.) in Raya Valley, Northern Ethiopia
}

\author{
Yemane Mebrahtu $^{1 *} \quad$ Haftamu Tamiru ${ }^{2} \quad$ Ahmmed Mohammed ${ }^{2}$ \\ 1.Department Irrigation and Drainage, Institute of Agricultural Research (EIAR), Mehoni Agricultural Research \\ Centre, Ethiopia \\ 2.Department Irrigation and Drainage, Ethiopian Institute of Agricultural Research (EIAR), Mehoni Agricultural \\ Research Centre, Ethiopia \\ 2.Department Irrigation and Drainage, Ethiopian Institute of Agricultural Research (EIAR), Assosa Agricultural \\ Research Centre, Ethiopia
}

\begin{abstract}
Irrigation technologies that save water are necessary to assure the economic and environmental sustainability of commercial agriculture. Precision irrigation scheduling is critical to improving irrigation efficiency. A field experiment was conducted to evaluate the responses of onion to irrigation regime (when and how much) and to identify water productivity under optimal irrigation regime. The study was conducted for three non-consecutive years at Mehoni Agricultural Research Center, Raya valley, Ethiopia. Five irrigation scheduling (60\% ASMDL, $80 \%$ ASMDL, 100\% ASMDL (FAO recommended ASMDL), 120\% ASMDL and 140\% ASMDL were used. The experiment was laid out in Randomized Complete Block Design (RCBD) with three replications. Bomby Red variety of onion was used for this experiment. Results showed that onion marketable, total bulb yield and water productivity was significantly affected by irrigation scheduling. The highest marketable onion bulb yields of 27.45, 26.92 and 26.76 ton/ha were obtained from treatment 60\% ASMDL, 80\% ASMDL and 100\% ASMDL, respectively. The lowest yield of 24.45 and 24.32 ton/ha was obtained from treatment $120 \%$ ASMDL and $140 \%$ ASMDL respectively. The highest water productivity (WP) of onion $5.81 \mathrm{~kg} / \mathrm{m}^{3}$ was obtained from treatment of FAO recommended available soil moisture depletion level followed by $+20 \%$ FAO recommended ASMDL, while the lowest value of $4.74 \mathrm{~kg} / \mathrm{m}^{3}$ was obtained from treatment $-40 \%$ or $140 \% \mathrm{FAO}$ recommended ASMDL. Therefore, based on the current findings, application of irrigation scheduling for onion in study and similar agro climatic area and soil type application of irrigation at 100\% ASMDL or FAO recommended gives highest bulb yield and water productivity.
\end{abstract}

Keywords: ASMDL, Irrigation scheduling, Onion, Water productivity

DOI: $10.7176 /$ JNSR/9-20-02

Publication date:October $31^{\text {st }} 2019$

\section{Introduction}

The ever increasing world population and the demand for additional water supply by industrial, municipal, and agricultural sectors exert a lot of pressure on renewable water resources forcing the agricultural sector to use the available irrigation water efficiently to produce more food to meet the increasing demand (Andarzian et al., 2011).

Determining crop yield response to irrigation is crucial for crop selection, economic analysis and for practicing effective irrigation management strategies. Furthermore, this enables to know the time of irrigation as well as to optimize yield, water use efficiency and ultimate profit (Payero etal. 2009). Under limited irrigation water supply, irrigation scheduling is also very useful in determining irrigation strategies. Irrigation scheduling is one of the most important tools for developing best management practices for irrigated areas (Pejic et al., 2008). Irrigation scheduling is the technique of applying water on a timely and accurate basis to the crop, and is the key to conserving water and improving irrigation performance and sustainability of irrigated agriculture (Lopez, 2004).

Jensen, M.E., (1980) referred to irrigation scheduling as "a planning and decision making activity that the farm manager or operator of an irrigated farm is involved in before and during most of the growing season". Irrigation scheduling has been described as the primary tool to improve water use efficiency, increase crop yields, increase the availability of water resources, and provoke a positive effect on the quality of soil and ground water.

Irrigation scheduling involves making a decision on how much and when to apply it. Three factors influence the decision: water needs by the crop (evapotranspiration), water availability, and water holding capacity of the soil (Mohamed and Makki, 2005).

Modern scientific irrigation scheduling uses a single approach or combination of weather-, soil- or plantbased approaches. This may involve estimating the earliest date to permit efficient irrigation or the latest date to avoid the detrimental effects of water stress on the crop (Ritchie and Johnson, 1991).

Keeping all above points in mind, the field experiment was planned, to evaluate the responses of onion to irrigation regime (when and how much) and to identify water productivity under optimal irrigation regime. 


\section{Materials and Methods}

\subsection{Description of experimental area}

The experiment was carried out under Mehoni Agricultural Research Center for three nonconsecutive years. It is situated at an altitude of 1578 meter above sea level (m.a.s.l). The area is characterized by bimodal rainfall pattern with a short rainy season (belg) and (kirmet), a long term average rainfall of $300 \mathrm{~mm}$, and its average minimum and maximum annual temperature is $180 \mathrm{C}$ and $320 \mathrm{C}$, respectively. Geographically the experimental site is located between $12^{\circ} 51^{\prime} 50^{\prime \prime}$ North Latitude and $39^{\circ} 68^{\prime} 08^{\prime \prime}$ East Longitude. The soil textural class of the experimental area is clay with $\mathrm{pH}$ of 7.1-8.1 (MehARC, 2015).
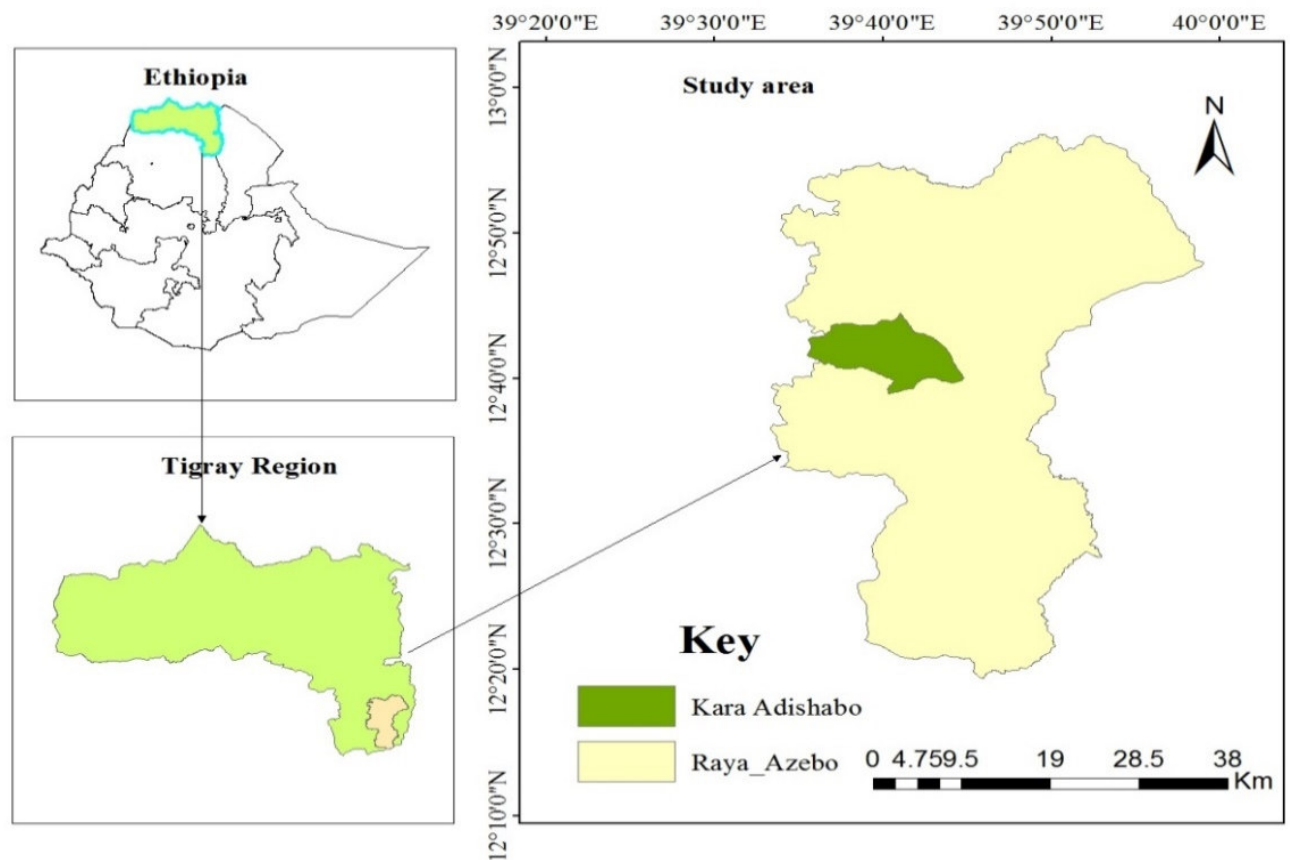

Figure 1. Map of the study area

\subsection{Climatic characteristics}

The average climatic data (Maximum and minimum temperature, relative humidity, wind speed, and sun shine hours) on monthly basis of the study area were collected from the near meteorological station. The potential evapotranspiration ETo was estimated using CROPWAT software version 8.

Table 1. Long term monthly average climatic data of the experimental area

\begin{tabular}{cccccccc}
\hline Month & $\begin{array}{c}\mathbf{T}_{\mathbf{m i n}} \\
{ }^{\circ} \mathbf{C}\end{array}$ & $\begin{array}{c}\mathbf{T}_{\mathbf{m a x}} \\
{ }^{\circ} \mathbf{C}\end{array}$ & $\begin{array}{c}\mathbf{R H} \\
\mathbf{\%}\end{array}$ & $\begin{array}{c}\mathbf{W i n d} \\
\mathbf{k m} / \mathbf{h r}\end{array}$ & $\begin{array}{c}\text { Sun } \\
\mathbf{h o u r s}\end{array}$ & $\begin{array}{c}\mathbf{R a d} \\
\mathbf{M J} / \mathbf{m}^{\mathbf{2}} / \mathbf{d a y}\end{array}$ & $\begin{array}{c}\mathbf{E T o} \\
\mathbf{m m} / \mathbf{d a y}\end{array}$ \\
\hline January & 11.5 & 27.2 & 73 & 69 & 7.9 & 18.4 & 3.33 \\
February & 12.8 & 27.1 & 70 & 86 & 9.4 & 22.0 & 4.02 \\
March & 13.5 & 29.5 & 68 & 86 & 8.7 & 22.4 & 4.44 \\
April & 13.8 & 29.7 & 67 & 95 & 8.7 & 22.9 & 4.65 \\
May & 15.3 & 32.5 & 58 & 52 & 9.1 & 23.3 & 4.69 \\
June & 15.8 & 35.0 & 60 & 43 & 8.6 & 22.2 & 4.70 \\
July & 15.6 & 31.5 & 90 & 52 & 6.5 & 19.1 & 4.04 \\
August & 15.0 & 29.7 & 95 & 43 & 6.5 & 19.3 & 3.89 \\
September & 14.3 & 30.8 & 74 & 52 & 6.6 & 19.2 & 3.96 \\
October & 13.1 & 29.8 & 69 & 86 & 9.2 & 22.0 & 4.36 \\
November & 12.1 & 28.6 & 67 & 69 & 9.0 & 20.1 & 3.77 \\
December & 11.3 & 27.1 & 69 & 69 & 8.8 & 19.0 & 3.40 \\
\hline
\end{tabular}

\subsection{Experimental Design and treatment combination}

The experiment was designed as randomized complete block (RCBD) arrangement with three replications. The experiment included five levels of soil water depletion. the five level of ASMDL are $(60 \%$ ASMDL, $80 \%$ ASMDL, $100 \%$ ASMDL (FAO recommended ASMDL), 120\% ASMDL and 140\% ASMDL). Predetermined amount of irrigation water were applied to each plot using Partial flume. 
Table 2: Treatment setting for field experiment

\begin{tabular}{ll}
\hline Treatments & Description \\
\hline ASMDL 1 & $60 \%$ ASMDL \\
ASMDL 2 & $80 \%$ ASMDL \\
ASMDL 3 & ASMDL* \\
ASMDL 4 & $120 \%$ ASMDL \\
ASMDL 5 & $140 \%$ ASMDL \\
\hline
\end{tabular}

*ASMD is available soil moisture depletion level according to FAO (33)

\subsection{Selected Soil and Water Properties of the Study Area}

The result of the soil analysis from the experimental site showed that the average composition of sand, silt and clay percentages were 15, 27 and 58\%, respectively. Thus, according to the USDA soil textural classification, the percent particle size determination for experimental site revealed that the soil texture could be classified as clay soil (Table 3 ).

Moreover, the $\mathrm{pH}$ value of the experimental site was 7.3. According to Tekalign (1991), soils having $\mathrm{pH}$ value in the range of 6.73 to 7.3 are considered neutral soils. And this value falls in the $\mathrm{pH}$ range that is very conducive for most vegetables and onion production.

The analysis of the irrigation water showed that $\mathrm{pH}$ value of 7.7 and $\mathrm{ECw}$ value of $0.46 \mathrm{dS} \mathrm{m}^{-1}$ were obtained. According to FAO (1999), water salinity has classification the irrigation water quality of the study area was classified at medium.

The $\mathrm{pH}$ of irrigation water is not a problem by itself, but it is an indicator of other problems such as sodium and carbonates. According to Bryan et al. (2007), the irrigation water was classified in the study area slight to moderate (7- 8) in terms of $\mathrm{pH}$ (Table 3 ).

The total available water (TAW) that is the amount of water that a crop can extract from its root zone is directly related to variation in FC and PWP and its root depth. Onion root depth extends only to $60 \mathrm{~cm}$ and hence the TAW of onion is $103.2 \mathrm{~mm}$. TAW of the experimental site soil was found to be $172.04 \mathrm{~mm}$ per meter depth (Table 4).

Table 3. Major soil and water characteristics of the experimental field

\begin{tabular}{lll}
\hline Soil parameters & Unit & Value \\
\hline Particle soil distribution & & \\
\hline Sand & $\%$ & 15 \\
Silt & $\%$ & 27 \\
Clay & $\%$ & 58 \\
Textural class & & Clay \\
\hline $\mathrm{pH}$ & - & 7.3 \\
$\mathrm{ECe}\left(\right.$ by $\left.25^{\circ} \mathrm{C}\right)$ & $\mathrm{dS} \mathrm{m}{ }^{-1}$ & 0.12 \\
Irrigation Water & & \\
$\mathrm{pH}$ & - & 7.7 \\
$\mathrm{ECw}$ & $\mathrm{dS} \mathrm{m}$ - $^{-1}$ & 0.46 \\
\hline
\end{tabular}

Table 4. Physical characteristics of soil at the experimental site

\begin{tabular}{lcccc}
\hline $\begin{array}{c}\text { Soil } \\
\text { texture }\end{array}$ & $\begin{array}{c}\text { Bulk density } \\
\left(\mathbf{g} / \mathbf{c m}^{\mathbf{3}}\right)\end{array}$ & $\begin{array}{c}\text { Field capacity } \\
\mathbf{( \% )}\end{array}$ & $\begin{array}{c}\text { Permanent wilting point } \\
(\mathbf{\%})\end{array}$ & $\begin{array}{c}\text { Total water holding capacity } \\
(\mathbf{m m})\end{array}$ \\
\hline Clay & 1.1 & 44.34 & 28.7 & 170.04 \\
\hline
\end{tabular}

\subsection{Experimental procedure and management practice}

The size of each individual plots had kept at $2.8 \mathrm{~m} * 3 \mathrm{~m}$. The spacing between plots and blocks were $2 \mathrm{~m}$ and 3 $\mathrm{m}$, respectively. The spacing between onion plants and rows was kept at $10 \mathrm{~cm}$ and $20 \mathrm{~cm}$, respectively. Each plot has 8 rows of onion plants with double row and 30 plants in each row with a total plant population of 400 in each plot. Each experimental treatment was fertilized with recommended fertilizer application, that was $100 \mathrm{~kg} / \mathrm{ha}$ and $100 \mathrm{~kg} / \mathrm{ha}$ of DAP and Urea respectively. The full dose of DAP was applied at transplanting, whereas Urea was applied by splitting into two parts, half first three weeks after transplanting and the rest just at mid-stage. All cultural practices were done to all treatments in accordance to the recommendation made for the area. Irrigation water was applied as per the treatment to refill the crop root zone depth close to field capacity.

\subsection{Irrigation scheduling}

The net depth of water required (dnet) was determined by the equation provided by

$$
\mathrm{d}_{\text {net }}=\mathrm{TAW} \times \mathrm{P}
$$


Where

$\mathrm{d}_{\text {net }}=$ Net depth of water required $(\mathrm{mm})$

$\mathrm{P}=$ Allowable soil moisture depletion by the crop

Irrigation Scheduling

TAW $=$ Total available soil moisture $(\mathrm{mm} / \mathrm{m})$.

The number of days between two subsequent irrigations, irrigation scheduling, was determined by using equation.

$$
\begin{aligned}
& \mathrm{IF}=\mathrm{d}_{\text {net }} / \text { ETc } \\
& \text { Where } \\
& \mathrm{IF}=\text { Irrigation frequency (days) } \\
& \mathrm{d}_{\text {net }}=\text { Net depth of water required }(\mathrm{mm}) \\
& \text { ETc = Crop evapotranspiration }(\mathrm{mm} / \text { day) }
\end{aligned}
$$

The crop evapotranspiration used in irrigation frequency determination was determined by using equation.

$$
\begin{aligned}
& \mathrm{ETc}=\text { ETo } \times \mathrm{Kc} \\
& \text { Where } \\
& \text { ETc }=\text { Crop evapotranspiration }(\mathrm{mm} / \text { day }) \\
& \text { ETo }=\text { References evapotranspiration }(\mathrm{mm} / \text { day }) \\
& \mathrm{Kc}=\text { crop coefficient }
\end{aligned}
$$

\subsection{Calculation of water productivity}

Water productivity (WP) is the amount of onion bulb yield per irrigation water applied.

$$
\mathrm{WP}=\frac{\text { harvested grain yield }}{\text { total water used }}
$$

Where, WP is crop water productivity $\left(\mathrm{kg} / \mathrm{m}^{3}\right)$, harvested bulb yield $(\mathrm{kg} / \mathrm{ha})$ and total water used is the seasonal crop water consumption by evapotranspiration $\left(\mathrm{m}^{3} / \mathrm{ha}\right)$.

\subsection{Statistical Analysis}

Analyses of variances for the data recorded were conducted using SAS 9.1 statistical software carried out using least significance difference (LSD) test at 5\% probability used for mean separation when the analysis of variance indicated the presence of significant treatment differences.

\section{Results and Discussion}

\subsection{Irrigation Water Requirements of Onion}

The water requirement of onion was computed for the growing season using the CROPWAT 8 computer program with climate, soil and crop input data from the study area. The values of ETo estimated using CROPWAT model based on climate parameters need to be adjusted for actual crop ET. The crop water requirement of the tested crop is calculated by multiplying the ETc with crop coefficient $(\mathrm{Kc})$.

According the seasonal irrigation water requirement of onion for 100\% ASMDL was in the study area 446.9 $\mathrm{mm}$. This amount of water for each treatment was needed for $60 \%$ ASMDL, 80\% ASMDL, 100\% ASMDL, $120 \%$ ASMDL and 140\% ASMDL of were $448.3 \mathrm{~mm}, 447.2 \mathrm{~mm}, 446.9 \mathrm{~mm}, 446.1$ and $444.3 \mathrm{~mm}$ respectively.

\subsection{Crop Growth and Physiology Parameters}

Analysis of variance has shown non-significant $(\mathrm{P}<0.05)$ difference in plant height, bulb length, bulb diameter, unmarketable bulb yield of onion. (Table 5). Numerically among the treatments the highest plant height, bulb height, bulb diameter and unmarketable bulb yield of onion was recorded from $120 \%, 140 \%$ ASMDL, $120 \%$ ASMDL and $60 \%$ ASMDL with the value $47.2 \mathrm{~cm}, 5.3 \mathrm{~cm}, 5.75 \mathrm{~cm}$ and $2.13 \mathrm{ton} /$ ha respectively. In the other hand, the shortest plant height, bulb height, bulb diameter and unmarketable bulb yield of onion was recorded from $60 \%$, 80\% ASMDL, 60\% ASMDL and 100\% ASMDL with the value $40.1 \mathrm{~cm}, 5.05 \mathrm{~cm}, 5.5 \mathrm{~cm}$ and 1.77 ton/ha respectively.

\subsection{Number of leaves per plant}

The analysis of ANOVA indicates that, there was significant $(\mathrm{P}<0.05)$ difference on the different treatment of available soil moisture depletion level (ASMDL) on onion number of leaves per plant. The highest number of leaves per plant (10.6) was obtained from treatments which received -20\% FAO recommended ASMDL followed by $100 \%$ FAO recommended ASMDL. The lowest number of leaves per plant was recorded from the treatment $+40 \%$ FAO recommendation ASMDL (Table 5).

The increase in number of leaves per plant at higher irrigation level and shorter irrigation interval was obviously due to maintenance of soil moisture regime in the root zone closer to field capacity. When moisture in the root zone is closer to field capacity, the nutrient availability is high and the plant does not experience moisture stress at any stage of growth and development. 
This finding is also in line with Ebtessan et al., (2016) reported vegetative growth parameters of onion crop including plant height, number of leaves per plant were significantly decreased by increasing soil moisture stress. The result of the current study is in agreement with the result of Bagali et al. (2012) reported that scheduling of drip irrigation onion at shorter interval with higher level of irrigation recorded significantly higher number of leaves. This finding is also in line with Metwally (2011) and Enchalew (2016).

Table 5. Effects of optimal irrigation scheduling on Plant height (cm), Number of leaf per plant, Bulb length (cm) and Bulb diameter $(\mathrm{cm})$

\begin{tabular}{lllll}
\hline Treatment & PH & NL & BL & BD \\
\hline 60\% ASMDL & 40.1 & $10.16^{\mathrm{ab}}$ & 5.16 & 5.5 \\
$\mathbf{8 0 \%}$ ASMDL & 46.9 & $10.6^{\mathrm{a}}$ & 5.05 & 6.01 \\
ASMDL* & 44.5 & $10.2^{\mathrm{ab}}$ & 5.11 & 5.62 \\
$\mathbf{1 2 0 \%}$ ASMDL & 47.2 & $9.8^{\mathrm{c}}$ & 5.2 & 5.75 \\
$\mathbf{1 4 0 \%}$ ASMDL & 43.1 & $9.5^{\mathrm{c}}$ & 5.3 & $5.66^{\mathrm{a}}$ \\
\hline LSD .05 & $\mathbf{N S}$ & $\mathbf{0 . 5}$ & $\mathbf{N S}$ & $\mathbf{N S}$ \\
CV $(\%)$ & $\mathbf{9 . 1}$ & $\mathbf{2 . 6}$ & $\mathbf{4 . 2}$ & $\mathbf{4 . 5}$ \\
\hline
\end{tabular}

*Means followed by different letters in a column differ significantly and those followed by the same letter are not significantly different at $P<0.05 ; L S D=$ least significant difference; $C V=$ Coefficient of variation.

\subsection{Marketable bulb yield}

The mean marketable bulb yield of onion was significant $(\mathrm{P}<0.05)$ difference on the different treatment of available soil moisture depletion level (ASMDL). The highest marketable bulb yield was obtained from treatments which received $60 \%$ FAO recommended ASMDL followed by $80 \%$ and $100 \%$ FAO recommended ASMDL with the result of 27.45, 26.92 and $26.72 \mathrm{ton} /$ ha respectively. The lowest marketable bulb yield of onion (24.32 ton /ha) was recorded from the treatment of $140 \%$ or $+40 \%$ FAO recommended ASMDL. There was no statistically differences observed among 120\% ASMDL and 140\% ASMDL on marketable bulb yield of onion (Table 6).

The better performance of yield parameters with 100 per cent may be attributed to significant increase in growth parameters. The result was in agreement with the finding of Bagali et al. (2012) reported that scheduling of drip irrigation onion at shorter interval with higher level of irrigation recorded significantly higher bulb yield. Similar results for higher bulb yield were reported by Anonymous (2001 and 2002) and Hanson and May (2004).

\subsection{Total bulb yield}

The mean total bulb yield was significant $(\mathrm{P}<0.05)$ difference on the different treatment of available soil moisture depletion level (ASMDL). The highest total bulb yield (29.58, 28.81 and $28.51 \mathrm{ton} / \mathrm{ha}$ ) was obtained from the treatment of $60 \%$ ASMD, $80 \%$ ASMDL and 100\% FAO recommended ASMDL respectively. In the other hand, the lowest value of total yield of onion ( 26.34 and 26.47 ton/ha) was recorded from the treatment of $140 \%$ and $120 \%$ FAO recommended available soil moisture depletion level.

The result of the current study is in agreement with the finding of Bagali et al. (2012) reported that scheduling of drip irrigation onion at shorter interval with higher level of irrigation recorded significantly higher bulb yield.

\subsection{Water productivity of onion}

The effect of different irrigation scheduling levels was significant $(\mathrm{P}<0.05)$ on onion water productivity. As showed in Table 6, the highest water productivity of onion was recorded from the treatments $100 \%$ FAO recommended ASMDL which has given $5.81 \mathrm{~kg} / \mathrm{m}^{3}$ followed by $+20 \%$ FAO recommended ASMDL. The minimum water productivity $4.7 \mathrm{~kg} / \mathrm{m}^{3}$ was obtained from $60 \%$ or $-40 \%$ FAO recommended ASMDL. Due to the reason of too much water frequently irrigated water and low water productivity.

Table 6. Effects of optimal irrigation scheduling on Marketable bulb yield (ton/ha), Un Marketable bulb yield (ton/ha, Total bulb yield (ton/ha) and Water productivity $\left(\mathrm{kg} / \mathrm{m}^{3}\right)$ of onion

\begin{tabular}{lcccc}
\hline Treatment & MBY & UMBY & TBY & WP \\
\hline $\mathbf{6 0 \%}$ ASMDL & $27.45^{\mathrm{a}}$ & 2.13 & $29.58^{\mathrm{a}}$ & $4.74^{\mathrm{c}}$ \\
$\mathbf{8 0 \%}$ ASMDL & $26.92^{\mathrm{a}}$ & 1.89 & $28.81^{\mathrm{a}}$ & $5.12^{\mathrm{bc}}$ \\
ASMDL* & $26.76^{\mathrm{a}}$ & 1.77 & $28.53^{\mathrm{a}}$ & $5.81^{\mathrm{a}}$ \\
$\mathbf{1 2 0 \%}$ ASMDL & $24.45^{\mathrm{b}}$ & 2.02 & $26.47^{\mathrm{b}}$ & $5.47^{\mathrm{ab}}$ \\
$\mathbf{1 4 0 \%}$ ASMDL & $24.32^{\mathrm{b}}$ & 2.01 & $26.34^{\mathrm{b}}$ & $5.35^{\mathrm{b}}$ \\
\hline LSD .05 & $\mathbf{1 . 5 1}$ & $\mathbf{N S}$ & $\mathbf{1 . 6 1}$ & $\mathbf{0 . 4 5}$ \\
CV $(\%)$ & $\mathbf{3 . 7}$ & $\mathbf{1 4 . 3}$ & $\mathbf{5}$ & $\mathbf{4 . 6}$ \\
\hline
\end{tabular}

*Means followed by different letters in a column differ significantly and those followed by the same letter are not significantly different at $P<0.05 ; L S D=$ least significant difference; $C V=$ Coefficient of variation. 


\section{Conclusion and Recommendation}

The experiment was conducted to study the effect of irrigation scheduling on plant height, bulb diameter, bulb length, bulb yield and WP of onion. The result showed that there was significant difference among the treatments regarding bulb yield and water productivity of onion. Based on the obtained results of the effect of different irrigation schedules, the highest bulb yield was obtained from the treatment of $60 \%$ ASMD, $80 \%$ ASMDL and $100 \%$ ASMDL without significance difference among the three treatment. In the other hand, the higher water productivity of onion was obtained from 100\% FAO recommended ASMDL. Therefore, based on the current findings, application of irrigation scheduling for onion in study and similar agro - climatic area and soil type application of irrigation at $100 \%$ ASMDL or FAO recommended gives highest bulb yield and water productivity.

\section{Conflict of Interests}

The authors have not declared any conflict of interests.

\section{Acknowledgments}

The authors are grateful to Ethiopian Institute of Agricultural Research, for providing finance funds for the implementation of the experiment and technical support. The authors also very grateful to Mehoni Agricultural research centre for all staff of Natural Resources Management Research core process for giving support in field management and technical guidance during the study of the experiment. Our special thanks go to Mr.Mogos Meresa and Mr. Abraha Tegegn for all their participation and dedication in the implementation of this experiment.

\section{Reference}

Andarzian, B., Bannayan, M., Steduto, P., Mazraeh, H., Barati, M. E., Barati, M. A. and Rahnama, A, 2011. Validation and testing of the Aqua Crop model under full and deficit irrigated wheat production in Iran. Agricultural Water Management, 100: 1-8. http://dx.doi.org/10.1016/j.agwat.2011.08.023.

Anonymous, 2001, Annu. Rep. (2000-01). NRCOG, Rajagurunagar, Maharashtra, India p. 60.

Anonymous, 2002, Annu. Rep. (2001-02). NRCOG, Rajagurunagar, Maharashtra, India, p. 70.

Bagali, A.N., Patil, H.B., Guled, M.B. and Patil, R.V. 2012. Effect of scheduling of drip irrigation on growth, yield and water use efficiency of onion (Allium cepa L.). Karnataka. Journal of Agricultural Science, 25(1) :116119.

Bryan, G.,Donald, A., and Robert, G. 2007.managing irrigation water quality for crop production, Washington state university.

Ebtessan A. Youssef and Sahar S. Taha. 2016. Effect of moisture stress and magnetized water on growth parameters and yield characteristics of onion plants. International Journal of Pharm Technology Research, 9(9): 104-111.

Enchalew, B., Gebre, S.L., Rabo M, Hindaye B, Kedir M. 2016. Effect of deficit irrigation on water productivity of onion (Allium cepal.) under drip Irrigation. Irrigation Drainage System Engineer, 5: 172. doi: 10.4172/2168-9768.1000172.

FAO (Food and Agricultural Organization), 1999. Soil salinity assessment methods and interpretation of electrical conductivity measurements. US salinity laboratory united states department of agriculture, riverside, California, USA.

Jensen M.E., 1980. Design and Operation of Farm Irrigation Systems. Monograph 3. American Society of Agricultural Engineering. Michigan, USA.

Hanson, B. R. and May, D. M., 2004. Response of processing and fresh market onions to drip irrigation, Acta Hort., 664: 399405.

Lopez-Urrea, R.,Olalla, F. M. D., Montoro, A. and Lopez-Fuster, P. 2009. Single and dual crop coefficients and water requirements for onion (Allium cepa L.) under semiarid conditions. Agricultural Water Management,96:1031-1036.

MehARC, (2015). Mehoni Agricultural Research Center, Land and water research process, Annual research report of 2014/2015, Maichew, Tigray, Ethiopia.

Metwall, A.K. 2011. Effect of water supply on vegetative growth and yield characteristics in onion (Allium Cepa L.). Australian Journal of Basic and Applied Sciences, 5(12): 30163023.

Mohamed, A.E. and Makki, E.K. (2005). Wheat Response to Irrigation Scheduling. University of Khartoum Journal of Agricultural Sciences 13(1), 53-66.

Payero, J.O., D.D. Tarkalson, S. Irmak, D. Davison and J.L. Petersen. 2009. Effect of timing of deficit-irrigation allocation on corn evapotranspiration, yield, water use efficiency and dry mass. Agricultural water Management, 96: 1387-1397.

Pejić, B., Gvozdanović-Varga, Vasić, J., Maksimović, M. and Milić, L. 2008. Yield and evapotranspiration of onion depending on different preirrigation soil moisture. (In Serbian). A Periodical of Scince Research Field and Vegetable Crops, 44:195-202. 
Ritchie, J.T., and B.S. Johnson. 1991. Soil and plant factors affecting evaporation. pp. 363-390. In B.A. Stewart and D.R. Nielsen (eds.) Irrigation of Agricultural Crops, Agron. Mono. No. 30, Am. Soc. Agron., Madison, WI.

Tekalingn Mamo, I.Haque and E. A. Aduayi. 1991. Soil, plant, water, fertilizer, animal manure and compost analysis manual. Plant science division working document 13, ILCA, Addis Ababa, Ethiopia. 